\title{
Quality of Healthcare Services in the Tengger Tribe Community of Ranu Pane Village
}

\author{
Sakir $^{1}$, Akhmad Habibullah ${ }^{2}$ \\ ${ }^{1}$ Lecture of Governmental Science Department, Universitas Muhammadiyah Yogyakarta \\ ${ }^{2}$ Student of Master of Government Affairs and Administration, Universitas Muhammadiyah Yogyakarta \\ 1mas.sakir@fisipol.umy.ac.id; 2 abizurkati@gmail.com \\ DOI: https://doi.org/10.18196/jgpp.61104
}

Article Info

Article history:

Received 01 Feb 2019

Revised 01 Mar 2019

Accepted 15 Mar 2019
Key Words:

Quality of Service, Healthcare Services,

Tengger Tribe.

\begin{abstract}
One of the primary functions of the state is to provide public services. Through their authority, the state is required to provide excellent service, in order to respond to public demands which gets increasingly complex. Ideally, high-quality public services should not only be given to people in the urban areas, but also towards marginalized people, including isolated indigenous communities. This study intends to determine the extent of the quality of the public services provided to the Tengger Tribe community in Probolinggo Regency, East Java. The research is conducted in Ranupane Village, Probolinggo Regency. And the research method used is qualitative method, with the techniques for collecting data are interviews, observation and documentation. Results showed that the quality of healthcare services for the people of Tengger Tribe was not optimal. The influential factors are local culture, geographical location, infrastructure and the quality of government official resources. As for the recommendations offered are for the regional government to give an optimal healthcare service, through the placement of health workers (doctors, nurses, midwives) with adequate experience, repair infrastructures and build health facilities on Maternity Cottage (Polindes) and Assisting Health Center (Pustu) level, and creating innovation in healthcare specifically for marginalized communities like the Tengger Tribe and other tribes in Indonesia, in order to create a synchronization between medical and non-medical treatments.
\end{abstract}

\section{INTRODUCTION}

Agus Dwiyanto (2005) stated that public services is one of the entry points for the Republic of Indonesia to achieve the big dream towards a country whose able to run good governance. However there are still assignments to be completed, that is, to be able to execute the regulatory and service functions at the highest quality without any discrimination as stated in Law no. 25 of 2009 regarding Public Service.

In essence, the State as an instituition functions mainly to provide service to the society (Rasyid, 1997:11). The State must provide and fulfill the basic needs and civil rights of citizens, both in the form of goods, services and administration. Historically, public service has always changed despite being substantially similar, to serve citizens. During the Old Order until the New Order, services was centralized, while in the era 
of reform or regional autonomy, services shifted towards becoming more decentralized (Gaffar, 2002: 172).

The concept of decentralization and regional autonomy, according to Sinambela (2010) has brought fresh air for changes in the practice of public services. By applying decentralization, public services will draw both the provider and their user closer, thus increasing the quality of service provided, in addition to encouraging participation from the community to be involved in decision making of the execution of public services. Furthermore, decentralization could expand public services from the urban areas to the more remote rural areas, even for indigenous hinterland communities (Dwiyanto, 2007).

However, in practice, for more than a decade of decentralization, the quality of public services has not changed significantly. People still felt services that was slow, convoluted, expensive, inefficient, corrupt, with arrogant conducts and actions from the officials, uncertainty in service time, demands for rewards and minimal facilities. (Dwiyanto, 2010:76). Those negative excesses are caused by a number of factors, such as (1) the orientation of bureaucrats who are still more concerned towards power interest as compared to public interest. (2) no accomodation of public interest to be involved in decision making, hence there is no meeting point between the Government with the community to achieve the common good (Kumorotomo, 2007).

Results from the GDS survey conducted (Dwiyanto, 2003) shows that the low quality of public services in many regions of Indonesia is caused by the involvement of subjective elements such as cronyism, political affiliation, and ethnic and religious similarities, so that the practice of discrimination in public services still occurs frequently. Moreover, a person's socio-economic factors are also a factor in the occurrence of such discrimination of service (Dwiyanto, 2003). Research conducted (Manufandu, 2009) shows that access to public services in rural areas, especially in West Papua is still very low. Of the 14 rural tribes studied, there were 5 tribes who did not have access to basic services at all, while the rest received very low quality services. 
The same is true from the indigenous communities in the Tengger Tribe, the tengger pole (the tengger people). The Tengger Tribe is a remote indigenous community that lives around the area in the heart of Mount Bromo located in Probolinggo Regency, East Java. Based on the distribution of language and patterns of social life of the community, the Tengger tribe is distributed around Probolinggo, Lumajang, (Ranupane, Senduro district), Malang (Ngadas Village, Poncokusumo district), and Pasuruan.

Those communal groups are the object of research relating to the quality of public services in the healthcare sector because there are still many problems, such as: First, geographical location. The location of the group's residence is in remote highlands of the hinterlands, so access to services from the nearest district is very difficult. Second, infrastructure, which are still lacking in those regions. Third, a reluctance (disposition) of officers to provide services to the community due to fear that comes from the myth of the community group. Fourth, the culture of the Tengger Tribe are still thick with magical superstition, animist and relatively closed. These factors became the constraints to optimal public services in these remote indigenous groups.

Therefore, this phenomenon is very interesting, because on the one hand the Government of Probolinggo Regency seeks to provide optimal healthcare services for all its citizens, but on the other hand this desire clashed with local customs and culture, geographical aspects, infrastructure and the attitude of the officials.

\section{LITERATURE REVIEW}

Healthcare and education services are the most fundamental services as well as the obligation for the state to guarantee the health and acumen of its people. The service must of course be adequate and has a quality and also can be accessed by all levels of society. But in some areas that still have hinterland tribes there are still discriminatory actions related to services provided especially on healthcare. 
This is due to a clash between customs and good intentions of the regional government in the process of public service. In terms of access, services and facilities provided by the government has to be carefully considered, given the acceptance of attitudes from the community will greatly influence every healthcare policy from the government.

In-depth study related to the extent of the quality of public services in the healthcare sector for isolated indigenous people, especially the Tengger Tribe Community in Probolinggo Regency is made very important to do so. In addition, it is also important to know the factors supporting and obstructing the quality of the healthcare public services in isolated indigenous peoples. It is to see the extent of government's role and policies in the quality of healthcare services for indigenous people.

Previous research namely from Savirani (2015: 25) in the Power, Welfare and Democracy Survey emphasizes that an important issue in social problems lies in the issue of welfare services, $70 \%$ of respondents see basic services such as education and healthcare and social security as a very important public needs to be the focus of attention, and therefore it must be fully provided and managed by the government.

Although in the context of the different focus, Mada and Rahmawati (2018) wrote an example in analyzing welfare issues (in this case healthcare access) in Kulon Progo. They are able to conclude that fundamentally, providing access to health for the community, has a very distinctive difference. Especially in the most important aspect in providing healthcare services lies in the existence of an initiative from the head of the region to provide innovative programs, and is not foreign to the community (Mada, et.al, 2018: 81). This confirms that the essence of the attitude and acceptance of the public in the quality of provision in public services is measured by whether or not regional heads provide information and socialization as well as diverse cultural approaches. 
Furthermore, if we look deeper at the quality aspects of healthcare services for the community, this gap can be seen in four community dimensions, including those related to effectiveness, security (in terms of minimum risk for patients), cost burden (calculated per-minimum) and finally the overall satisfaction (Simpiagel in Susanti, 2009). From this opinion it is worth saying when the focus of the research refers to the in-depth study related to community satisfaction, because this is what supports the success of the quality of public services from the local government. From this notion it is worth saying when the focus of the research refers to the in-depth study related to the overall satisfaction of the community, this is because it is the thing that supports the success of the quality of public services from the local government.

In line with what was later put forward by Jacobalis in Susanti (2009), the most important access to quality healthcare services can be seen from two different approaches, including; First, an approach that focuses on the participation of the healthcare system and the health status of the people in a country. This covers the degree of disability, physical and mental development of the community and access to public healthcare. Second, the institutional or individual approach, the quality of healthcare services is a product of efforts to manage facility resources as well as individual activities. Therefore there are things that are important in indicating public services which can be distinguished by indicators, criterias and standards.

Lovelock (1992: 225) states that the important thing to be emphasized in the quality of public services, are: Tangible, Reliable, Responsible, Guarantee, and Empathy. These five things become the focus of attention in healthcare quality services. This is in line with what will be the focus of research.

\section{METHOD}

This research is a descriptive-type research with a qualitative approach. (Nawawi dan Martini, 1994) explained that descriptive methods are procedures or ways to solve research problems by describing the state of the object being investigated (person, institution, society, etc.) as it is, based on actual facts at the present time. Qualitative research according to Bogdan and Taylor in Moleong (2012: 4) 


\section{RESULTS}

If you hear the word tribe, some people's minds tend to point and conclude on things that are discriminatory and primitive. But legally they are still part of the Republic of Indonesia which cannot be separated. This means that they also have the same rights as urban communities in receiving public services from the state.

In this regard, this study discusses the quality of healthcare services in the Tengger Tribe, Probolinggo Regency. In this study there are 5 indicators that could answer the findings in the field related to the quality of healthcare services. The following are 5 indicators that affect the quality of healthcare services in the Ranu Pane Village:

\section{Tangibles (Physical Appearance)}

Facilities are one of the most important things in supporting the implementation of maximum service to the community. Without adequate support, any kind of human resources would not be maximal in providing services, especially in the healthcare sector. at Pustu Tengger Tribe, Ranupane Village, facilities available are still considered lacking to support the implementation of exceptional healthcare services.

To ensure optimal services, at least there must be devices in healthcare services such as facilities/service tools available at health centers, such as incubators, and medicines as facilities. Means and infrastructures for customer service are also very important to support the level of community satisfaction with the quality of health services.

In addition to adequate medical facilities and supported by infrastructures for customer service and complaints, Pustu (health centers) must also be equipped with medical personnel or midwives who must have ethics while providing services, at least in matters of appearance. Because what someone wears usually can strengthen the personality of that person. The appearance of a clean and neat officer can also add to the trust and satisfaction of the community in receiving services.

The image below is a number of facilities owned by the Ranupane Health Center to support the quality of service to the community. There are several rooms that can 
be used to carry out healthcare services such as examination rooms, general treatments, waiting rooms and restrooms. Although in some points the building has a leak due to rain.

Picture 1.

Facility on Pustu Ranupane, Suku Tengger

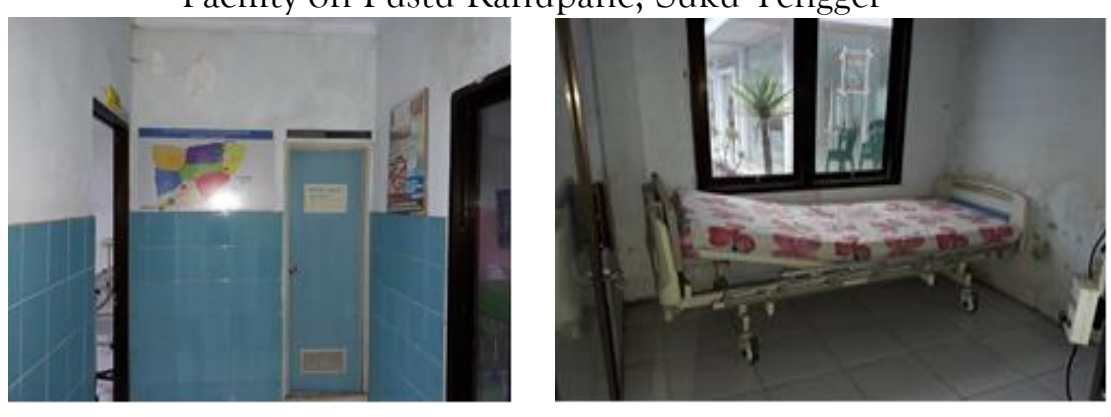

Source: Pustu Ranu Pane, Tengger Tribe.

Aside from physical structures in the form of buildings, the facilities and infrastructures available are still very lacking considering the needs of the people who are quite far from the the City. Such as the incubator tool that should have been replaced because it no longer works. Such tool is very useful if at any time there are people who give birth and experience health problems with their babies due to weather conditions that are quite extreme compared to other regions. Also oxygen tubes and several other medical devices so that patients who need special handling can be treated immediately.

\section{Responsiveness}

Human Resources is a factor that is not less important in implementing healthcare services. The responsiveness of midwives in serving the community affects the level of satisfaction of the community as patients of healthcare services at the Pustu Ranupane. Prompt service is also a reference for the level of satisfaction in shaping people's perceptions of service at the Ranupane Health Center. In addition to the accuracy and speed in providing services, midwives as health care providers in the midst of the community must also be approachable in order to provide maximum service to the community. 
There are three things about responsiveness in health services, namely; responsiveness in providing services, accuracy in serving the community and finally, providing assistance to people who need help outside of hours of service, such as caring for people who must be cared for at home.

There are three things regarding responsiveness in health services; promptness in providing services, accuracy in serving the community and finally, providing assistance to people who need help outside of hours of service, such as caring for people who must be cared for at home.

The variety of community assessments in the performance of midwives as community health service providers in Ranupane Village, Tengger Tribe, makes it a reference towards evaluation of the performance of midwives in carrying out services to the community in order to better themselves. Because the community assessment is the only source that can influence the optimization of the quality of services provided to the community. The following are the results of interviews with the community in Ranupane Village, Tengger Tribe:

"Midwives in Ranupane are very responsive when needed, also often picking up patients using ambulances. If the pain is severe, it will be taken using an ambulance and referred to Probolinggo" (Interviewed at 07 November 2017, 14.25 WIB).

Above are excerpts of interviews with the Tengger people who know the truth about how midwives respond when needed by the community. According to residents, it is not uncommon for midwives to come to the house if patients or residents who are sick cannot be taken to the health center, and some even get treated at home and the midwives are fully responsible for the patient's condition, such as administration of drugs, IV replacements when needed, among other health service standards.

Meanwhile, The following statement is from Mrs. Riska as a midwife who handles health complaints in the Pustu Ranupane, Tengger Tribe, when interviewed:

"I often visit residents' houses, hoping to check the health of the community in each house. Then I also often go back and forth to check the health of the whole 
community in the Ranu Pane Region" (Interviewed at 06 November 2017, 16.25 WIB).

Turned out that services was not only done in the health center, but midwives in Ranupane were also able to provide door-to-door service, which was one of the efforts to provide optimal service to the community. Furthermore, accompaniment is also often done, if there are patients who must be referred to the hospital and need more intensive treatment. Like pregnant in labor and so on.

\section{Reliability}

Ease of obtaining health services is one of the reason residents come and seek treatment at Pustu Ranupane. Simple and easy administration characteristic of services in rural health centers.

The ease of procedure in registering to get service is considered very far from a difficult word. Then, the accuracy of services to the community, as well as guarantees and trust is also one of the reliability in services.

Most people disagree about the adequacy of health care workers, who are only two people. As seen in the tables and graphs, the community considers that the midwives, which there are only two person, is still very lacking. This is due to the activities of midwives outside the village who sometimes require them not to stay in the health center for days, not to mention in the weekends, the midwife on duty goes home and returns to the village on Monday.

Because, according to residents, services needed for healthcare matters should be available anytime, not just on weekdays. People could be sick on times when midwives are not in station thus people have to travel far with bad road conditions and extreme weather. Furthermore the residents expect a better schedule so that there are officers available on holidays.

In addition, considering that the Tengger Tribe in Ranu Pane Village has a fairly high population, and also the village as a climbing trail and entrance to Mount Semeru, residents wanted a doctor to be available in the village, if at any time there are 
10 people who really need doctors handling, there is no need to travel far and leave the village.

\section{Security (Assurance)}

Ethics is one of the things that is considered in the approach to the community. With hospitality and politeness in providing services to the people of Tengger Tribe in Ranupane Village, health care officers are required to be friendly and polite in providing services to citizens and the community.

In addition to serving with hospitality and politeness, midwives must also guarantee security and trust in the services provided to the community. Ensuring security and providing trust in health services to the community are the primary basis that is a must have by health care staffs anywhere.

Expertise and skilled in providing services also become a reference for the level of community satisfaction regarding the quality of service which will provide good output towards the community's trust for checking and treatment at the Ranu Pane Health Center.

The expertise and skills possessed by Midwives have to be able to provide the best service even though the number of midwives in the Pustu Ranupane is limited. This creates special attention by the community, and thus the competence and security of health workers must be increased.

\section{Empathy}

The empathy of a midwife in healthcare services is also required when providing health assistance to the community. Such as willing to take action quickly and precisely outside the specified service hours to help people in need.

When providing services, communication is certainly one of the important tools in providing information. Smooth communication indicates that there is closeness, in this case between the healthcare workers and the Tengger Tribe people in Ranupane Village. The amount of care by the midwives in helping to solve problems that the community complained about is one form of service to the community with the aim of improving the quality of healthcare services in the Ranupane Village Health 
Center. The Tengger Tribe community considers that Midwives have a strong empathy in helping community problems.

Factors Affecting the Quality of Healthcare Services in the Tengger Tribe Ranupane Village, Probolinggo Regency, East Java

\section{Local Culture}

Indigenous cultures or customs are a set of habits of a group or community. The relation with the quality of public services is that the culture is often a limiting factor or a supporting factor for public services, because habits that have been passed down through generations are very difficult to change. Usually when traditions that has lasted for a long time collides with new policies that must be adopted will become obstacles in public services.

Like the culture and customs that exist in the Tengger Tribe, providing basic services in the form of healthcare in Ranupane Village through the village government, they have tried to provide these services to all of their communities, majority of which are descendants of the Tengger Tribe. There are customs and methods in curing diseases that they had with their own traditional ways. Even though there is already an alternative medical treatment in the village.

Suwuk is a method of treatment carried out by some people of the Tengger Tribe in the village of Ranupane. Suwuk is done by people who are believed to be able to treat certain diseases, the method used is usually by incantations and spell with water as a medium, then the water can be drunk or rubbed on people who are sick. Usually this treatment is used more towards toddlers and children.

\section{Geographical Location}

The geographical location of the existing rural tribes is a factor in the low access to public services. Usually the location of an hinterland tribes in Indonesia does have quite remote and difficult to access. Tengger tribe is no exception, as they are within the area of Mount Bromo and the foot of Mount Semeru. Access to Ranupane village is quite difficult, with winding terrain, uphills and downhills, with inadequate road infrastructure, making the village difficult to reach. 
Not to mention the weather, if it rains, only certain vehicles such as jeeps can pass. Sometimes according to some local residents, if the rain falls it usually results in landslides and fallen trees which creates obstacles that are very difficult to pass and even sometimes impossible to do so thus having to find an alternative way. This is one of the causes of the difficulty in distributing healthcare services.

\section{Infrastructure}

Infrastructure is often interpreted as a general means and ways to support economic activities in an area. Infrastructure is very important for public services because they will run well if supported by the available and adequate infrastructure, including public services in the healthcare sector. The availabilty of infrastructure such as roads to access to healthcare services, physical buildings of health centers themselves as providers of services, transportation, energy and telecommunications are essential for the implementation of topmost service.

The infrastructure in Ranupane village is still far from proper, infrastructures from various aspects must be improved, especially telecommunications services that are often complained by residents, because the network signals are still very limited, this is considered necessary to support health services via telecommunications. If it can run well, patients who cannot come to the health center will be able to contact healthcare workers through telecommunications networks. As for transportation, the infrastructure available is in the form of an ambulance provided by the Pustu if at any time there are patients who have to be rushed to the hospital to get more intensive care.

However, transportations available must also be accompanied by adequate road infrastructure. Other infrastructures such as physical buildings in the form of buildings must also be considered along with the necessary healthcare supporting tools. Because it turns out that the infrastructure is still felt to be inadequate given the community's needs in the healthcare matters that cannot be negotiated. This is what makes people and residents in Ranupane Village sometimes prefer to go to Malang and Probolinggo for treatment. 


\section{Human Apparatus Resources}

Human Apparatus Resources is the ability of the employees to do work that is imposed. Human Apparatus Resources is a determinant factor for improving organizational performance. In this case the human resources in providing health services in Ranupane Village are two health workers or midwives with workloads to serve the community with large populations.

With two midwives on duty and a high enough workload, this has the potential to create low service quality because the workload is too arduous. Addition of resources is an alternative that can be done by the village government. Other than the quantity of resources, it must be seen that the quality of resources must be improved.

\section{CONCLUSION}

Based on the results of the research conducted, the following conclusions can be drawn:

1. Health services provided by the local government to marginalized communities in the Tengger Tribe Ranupane village is generally not good enough.

2. From the 5 dimensions of service quality, the dimensions of tangibles are the lowest in the Tengger people.

3. There has been no innovation in special healthcare service programs formulated for remote indigenous communities such as the Tengger tribes and others.

4. The quality of health services in the Tengger Tribe is influenced by several factors, such as local cultures or customs which sometimes collide with the value of modern health services; the remote geographical location is also relatively difficult for residents to access; limited infrastructure and low quality of government apparatus resources. 


\section{REFERENCES}

\section{Book}

Dwiyanto, Agus, 2003. Reformasi Birokrasi di Indonesia. Yogyakarta: PSKK UGM.

Hardiansyah, 2011. Kualitas Pelayanan Publik: Konsep, Dimensi, Indikator dan Implementasinya. Yogyakarta: Gaya Media.

Kumorotomo, Wahyudi. 2005. Pelayanan yang Akuntabel dan Bebas dari Praktek KKN, dalam Agus Dwiyanto (Ed), Mewujudkan Good Governance Melalui Pelayanan Publik. Yogyakarta: UGM Press.

Kumorotomo, Wahyudi. 2005. Akuntabilitas Birokrasi Publik Sketsa Pada Masa Transisi. Yogyakarta: Penerbit Pustaka Pelajar.

LAN, 2003. Sistem Administrasi Negara Kesatuan Republik Indonesia (SANKRI), Buku I Prinsip-prinsip Penyelenggaraan Negara. Jakarta: Perum Percetakan Negara.

Moleong, Metode Penelitian Kualitatif, Bandung, Remaja Rosdakarya, 2012

Mada, S., \& Rahmawati, D (2018). "Rezim Kesejahteraan Universal: Kasus Kulon Progo." dalam Politik Kesejahteraan:Kontestasi Rezim Kesejahteraan di Indonesia, Yayasan Pustaka Obor Indonesia, Jakarta.

Nawawi dan Martini. 1994. Penelitian Terapan. Yogyakarta: Gajah Mada University.

Ratminto dan Winarsih, 2005, Manajemen Pelayanan. Yogyakarta: Pustaka Pelajar.

Sugiyono (2011), Metode Penelitian Kualitatif, Bandung: Alfabeta.

Savirani, A., \& Tornquist, O (2015). "Reclaiming The State: Overcoming Problems of Democracy in Post-Soeharto Indonesia. PolGov: Yogyakarta.

Susanti, Ulfah, 2009. Akses Keluarga Miskin Terhadap Kualitas Pelayanan Kesehatan di Rumah Sakit (Studi: Di Rumah Sakit Umum Patmasuri Yogyakarta), Skipsi.

Tjiptono, Fandi. 2000. Manajemen Jasa. Yogyakarta: Andi Offset.

Widjaja, HAW. 2008. Otonomi Desamerupakan Otonomi Yang Asli, Bulat Dan Utuh. Rajawali Pers.

Zeithaml, VA. Parasuraman and LL Berry, 1990. Delivery Quality Services: Balancing Customer Perceptions and Expectation. NY: The Free Press.

\section{Journal}

Chatre, Ashwini. 2008. Political Articulation and Accountability in Decentralisation: Theory and Evidence from India. Conservation and Society 6(1): 12-23

Raharjo, Warsisto. 2012. Inkonsistensi Paradigma Otonomi Daerah di Indonesia : Dilema Sentralisasi atau Desentralisasi. Jurnal Konstitusi, Volume 9, Nomor 4 